\title{
DEFAULT RISK PREMIUM AND EQUITY RETURN OF NON-FINANCIAL COMPANIES OF PAKISTAN
}

\author{
SADDAF ADALAT \\ Capital University of Science \& Technology, Islamabad, Pakistan
}

\begin{abstract}
The current study was aimed to examine the relationship between default risk premium and equity return by using sample of hundred companies from period between 2000 and 2015, listed at Karachi Stock Exchange. The firms are chosen on the basis of market capitalization. To examine the role of market premium, size premium, value premium and default premium in estimating the equity returns, the two pass regression was used. It was found that CAPM is valid model as market premium is priced but explanatory power is low. Similarly, the findings suggested that the CAPM model is not better than Fama and French model. Default risk premium is also significantly influencing equity returns. The study findings provided evidence about premium of default risk anomaly in Pakistani markets during the sample period. In default sorted portfolio the low default stocks earn lower than the high default stocks. This study has implications for decision markers in estimating cost of equity as well as weighted average cost of capital as it provides more information in comparison to CAPM. Moreover, information about premium of size, value and default anomaly may facilitate under developing investment strategies.
\end{abstract}

\section{INTRODUCTION}

Modern finance is based on different interconnected Asset Pricing Theories (e.g. Black, 1972; Sharpe, 1964) which include the capital asset pricing (CAPM) model (Cox, 1985; Rubinstein, 1976), Model of Merton (1973), as well as Theory of Arbitrage Pricing (APT) (Ross, 1976). In literature the Capital asset pricing (CAPM) model is a leading model. Whereas, in literature the multi factor asset pricing models is also discoursed.

Fifty years ago foundation of modern finance was laid down by Markowitz. His contributions are diversification, systematic risk and computation of portfolios risk and returns. Markowitz $(1952,1959)$ said that on the basis of mean variance theory investors selected their portfolios, which are risk averse. Tobin (1958) and Markowitz's (1952) worked on structure of portfolios. The work of Markowitz on portfolio altered the whole theory of finance in 1952. His work is further extended by Sharpe's paper on Capital Asset Pricing Model (CAPM) who added a concept of risk free security (RF) and provided method to measure systematic risk. The systematic risk refers to asset sensitivity to market specific factors. Therefore, higher the systematic risk demands, higher are the required rate of returns. On the basis of mean variance, Lintner (1965) and Sharpe (1964) found the Capital asset pricing (CAPM) model and explained it through efficient portfolio frontier.
The arbitrage pricing theory (APT) has been studied in several markets. Banz (1981) examined the linear relation between market risk and return of security in Capital Asset Pricing Model (CAPM) along with the stocks return and value of NYSE from 1926 and $1975 . \mathrm{He}$ introduced size effect that big firms have lower returns than smaller firms. Reinganum (1981) in the New York stock Exchange (NYSE) and American Stock Exchange (ASE) used APT to measure the impact of returns and prices of assets. Chen (1986) also studied Japanese Stock Market by using APT. Mirza and Shahid (2008) checked the applicability of Fama and French model's three factors, in Pakistan equity market and why should the Fama and French three factor model be used.

The CAPM introduction started discussion in literature regarding investor's demands rate of return on risky holding securities. The CAPM to multi factor models has developed from literature, which deals with the financial asset of pricing. Carhart (1977) and Fama and French (1993, 1992, 1996, and 1998) used the single factor of CAPM model and expanded it to develop multi factor models with value (book to market), size, investment, momentum and profitability. The CAPM is tested with passage of time in different settings and it has been criticized by many researchers, as well.

Capital asset pricing model and CAPM by Lintner (1965) and Sharpe (1964) identified many anomalies. Benz's (1981) size anomalies indicated that small stocks 
outperform companies as compared to big companies. Basu (1986) identified the $\mathrm{P} / \mathrm{E}$ ratio and found that high $\mathrm{P} / \mathrm{E}$ ratio companies have high returns than low $\mathrm{P} / \mathrm{E}$ ratio companies. Rosenberg, Reid \& Lanstein (1985) and Stattman (1980) identified value anomaly that firms with low $(\mathrm{B} / \mathrm{M})$ book to market value perform lower than firms with high $(\mathrm{B} / \mathrm{M})$ book to market value. Similarly, Amihud and Mendelson (1986) reported liquidity anomaly. Jegadeesh and Titman (1993) indicated that the stocks having low returns firms (the loser) earn lower than stock having high return in past (the winner).

The anomalies of CAPM developed the theoretical model proposed by Ross (1976), which is an arbitrage pricing theory (APT). The inspiration of arbitrage pricing theory came from the famous three factor model proposed by Fama and French $(1993,1996)$. The three factor model consists of value premium that explains $\mathrm{B} / \mathrm{M}$, size premium, which explains the size and market premium related anomalies. The model is well accepted. Carhart (1977) identified momentum anomaly to expand the Fama and French model, which indicates that the price momentum effect are related to CAPM anomalies.

Various markets across the world have examined the SMB and HML Fama and French factors but in Pakistan equity market, no detailed study of default risk exists. The Pakistan equity market is one of the rapid growing markets, getting investors' interest. The Fama and French (1998) indicated that value and size factors are country specific factors, rendering Pakistani equity market important to discover the factor priced.

In financial market the relationship between stock returns and default risk has a significant association with the reward risk trade-off. In order to bear the risk, the investors accept a positive risk premium, when systematic is default risk. Evidence from market inefficiency is taken that the default risk and realized stock returns have negative relationship. The SMB and HML, the factors of Fama and French (FF) have some information related to default; the equity returns are not completely explained by FF model. However, Elton et al.'s (2001) study used aggregate default spread to measure the default risk, which is in line with the Merton (1974) and Black and Scholes (1973), who used conditional claims methodology to measure default risk. The risk factors of Fama and French (1993) do not posit that the stocks with high default risk have low returns.

A study by Dichev (1998) indicated that the default risk and equity return have negative relationship. Financial distress is measured by using Ohlson's O score and Altman's Z score from year 1981 to 1995 . Hillegeist, Keating, Cram, and Lundstedt (2004) suggested that Z score and $\mathrm{O}$ score calculating power are limited and supporting measure used is based on the Merton (1974) option pricing and Black and Scholes (1973) model; therefore, MKMV is used to measure expected default frequency EDF. Vassalou and Xing (2004) measured the expected default frequency EDF and probability of default. Results indicated that small companies with high book to market and high probability of default can earn more return than small companies with low probability of default. They also found that the default risk is priced positively in returns of stock and the nature default risk is systematic.

Fama and French (1995) studied that default risk is measured by proxy of size and value (book to market) and equity returns is priced. Numerous researchers examined default risk measure and compared predictive power of cross section returns with book to market factors (Dichev, 1998; Vassalou \& Xing, 2004; Griffin $\&$ Lemmon. 2002). These studies ensured that there are different measures of default risk for different firms. However, these measures are weak predictors of return premium as these indirectly measure the default risk.

The aim of study is to explore the Pakistani market and find out the equity returns and default risk relationship between them. Default is one of main attributions of securities in capital market. The financier demands the stocks, which have high default risk and can earn high return as compared to the stocks that have low default risk and earn low return. In recent years, default risk has been proven to have attracting significant of asset pricing models.

\section{REVIEW OF LITERATURE}

The current study explores the area of asset pricing, which is related to the developing literature. Griffin (2002) indicated that the default risk and returns of stock have negative relationship between them by building on the theoretic base. Garlappi et al. (2008), Fan and Sundaresan (2000) through their studies suggested that the default risk and returns of stocks have negative relationship, which is explained by absolute priority rule (APR); further concurred by Dichev (1998). Avramov et al. (2007) proposed that the high default risk stocks can earn negative returns; whereas, George and Hwang (2008) explained the anomaly of leverage and their results indicated that returns and leverage have negative relationship. Vassalou and Xing (2004) explained the return and distress risk stock and their results indicated that high returns can be earned by small companies.

Dichev (1998) posited that the returns of stocks and probability of default have an opposite relationship between them. By expanding the Altman (1968) Z-score and Ohlson (1980) O-score study, which were used to measure the probability of default. This is also established by Griffin (2002), whose results indicated that the companies with high default risk and low book 
to market ratio can earn the lower returns and it leads to stock mispricing in the market. Likewise, Chava and Jarrow (2004), Shumway (2001), Campbell, Hilscher, and Szilagyi (2004) used the hazard model approach model to calculate the factors of corporate default risk.

Gertner, \& Sharfstein (1994), as well as Opler and Titman (1994) in their respective studies found that the default risk is not symbolized as systematic risk and related to individual factors. Denis and Denis (1995) studied that the business cycle changes from companies to companies and the default risk is associated to the factor of macroeconomics. Fama and French (1996) stated that proxies of default risk are SMB and HML factors. Vassalou (2003) further stated that many of information of default risk comprise by the factors of SMB and HML, but these are unable to capture full default risk premium reported in the returns of equity. The factors SMB and HML appear to contain no information about the default risk but have other important information. Correspondingly, explanation of the risk based premium is also discussed by Li, Vassalou and Xing (2000).

Berndt, Duffie, Schranz and Ferguson (2005), Philippon and Almeida (2007) and White, Hull and Predescu (2004), in their respective studies stated that between the adjusted risk, there are considerable differences and physical probabilities of default. Various methods have been used in literature. On the basis of stock ranking, the probability of default is indirectly measured from historical data of default, and is completed by Campbell, Szilagyi and Hilscher (2008) and Dichev (1998). Inside structure of the q-theory, Liu, White \& Zhang (2009) and Cochrane (1991) suggested that companies with low default probability can earn low returns. Likewise, the companies having high leverage can earn future returns of stocks low (Xing \& Zhang, 2009; Korteweg, 2010). Establishment with Chance (1990), Cox \& Black (1976) along with Merton (1974, 1977) model, Cooper and Mello (1991), Johnson and Stulz (1987), Singer and Ho (1982) indicated that the company's values fall down when debt is low in time and the debt maturity is occurred by default model. Further in recent times, Schwartz and Longstaff (1993) and White and Hull (1992) proposed the default modeling allowed by magnitude fixed for default time period is random and for the first time the pre-specified boundary of default reached to the value of firms.

Dempsey (2010) studied the context of Australian stock markets in order to investigate the value stock (book to market ratio) relationship for the construction of returns of stocks. For expanding the capital asset pricing model (CAPM) the Fama-French three factor model is developed, which is designed with two portfolios and used to capture the risk premium, which are size premium (small minus big) and value premium (book to market ratio). The size premium (small minus big) and value premium (book to market ratio) are the elements used for the proxies of risk. The stock returns are explained by the Fama and French three factor model and by investigating the nature of relationship between value stock (book to market) and returns of stock. The results indicate that the value stock book to market ratio and returns of stocks have positive relationship between them. Hsu, SaaRequejo \& Santa-Clara (2004) suggested that when the efficient capital market conveys, the value of firm falls down below the default risk. The classification of default makes the model more manageable.

The five factor model is further extension by Fama and French (1993) to measure effect of market, effect of size, value effect, term effect and default effect by using time series regression of bonds and stocks of listed companies on NYSE. The market effect, size effect and value effect are significant for stocks and term effect and default effect are significant for bonds. On the basis of result the three factor asset pricing model is proposed by Fama and French (1993) for stocks, which includes the effect of market, size effect and value effects. The capital asset pricing model (CAPM) has further extended to the three factor model. The effect of size measure that companies with high market capitalization can earn lower return than the companies with low market capitalization. The effect of value measure the companies with low book to market ratio can earn low returns than the companies with high book to market ratio.

Fama and French (1996) examined returns and value (book to market ratio) relationship between them. The expected returns of beta alone cannot be explained by Capital Asset Pricing Model (CAPM). The Lintner (1965) and Sharpe (1964) have two negative results for Capital Asset Pricing Model (CAPM) measured by Fama and French (1992) and their results indicated that the variation of beta market is unrelated to size, as beta is not sufficient to explain average return. Fama and French (2015) the Five Factor Model explains value effect, size effect, profitability and investment effect, as well as investment designs in returns of stock, which provide that these factors can better explained return in comparison of Fama and French (1993) to the three factor model. The small stocks can earn low returns that behave like the firms that invest in low profitability, which were not captured by the five factor model. The study examined the profitability and investment factors that are found non-significant in explaining the average returns.

Das, Freed, Geng \& Kapadia (2002) examined the correlation between default risks for US non-financial firms. The study stated that if correlation between defaults increases, it will lead to increase in the level 
of default risk and both can expect loss. The results state that the default probability is positively correlated and vary over time. The correlation varies across firms systematically, which is related to economy wide level of default risk. Allen and Powell (2007) used the KMV/ Merton structure methodology, which includes market asset values, to examine default probabilities (PD) of 58 banks in Australian market and made comparison internationally. They further modified the model for conditional probability of default and result, stated that the lenders to bank assess default probabilities and manage capital adequacy accordingly.

Vassalou and Xing (2004) calculated the default risk measure for the companies by using Merton's option pricing model (1974) and measured the impact of default risk on the returns of equity. The three factor model by Fama and French (FF) has some information of default risk, size (small minus big) and value (book to market) factors and the results indicated that big companies have low returns than smaller companies as the big companies default risk is low. The observation that the low returns are received by the companies having low default risk from the companies having high default risk is consistent with high risk and high return argument.

Bystrom, Worasinchai \& Chongsithipol (2005) and Merton (1974) used default probability model to examine the firms listed in SET50 index at Stock Exchange of Thailand (SET) to examine the relation between default probability of firms with value (book to market ratio) and size (small minus big). Outcomes of study stated that risk of distress is systematic in nature and by higher returns it is compensated. Patel \& Vlamis (2006) and Black and Scholes (1973) used Merton option pricing (1974) model/KMV approach and to estimate the distance to default and the probabilities of default for 112 companies listed at London Stock Exchange from 1980 to 2001.

Gharghori, Chan and Faff (2009) described the variation in cross section of returns of equity by employing the value (book to market) and size, since these factors are used for default risk proxy and results indicate that size and book to market are not default risk proxies and results state that the default risk and returns have negative relationship between them.

An Australian study by Gharghori, Chan and Faff (2007) in Australian market used the Fama and French (1993) model and used SMB and HML factors of Fama and French in order to explore the variation in returns of equity. Their study considered that default risk is measured by the proxy of two FF factors, i.e. SMB and HML. The main contribution of study is that the returns of equity are explained by factors of Fama and French factors, because these measures are priced. The results indicate that the returns of equity are not priced by default risk and the nature is not systematic for default risk, whereas the default risk is not considered as proxy measured by Fama and French factors. Furthermore, the study concluded that results of Australian market are inconsistent with Vassalou and Xing (2004) results in US.

Spyrou and Kassimatis (2009) explained data for twelve European markets, i.e. Australia, Denmark, Germany, France, Ireland, Greece, Italy, Netherland, Sweden, Spain, UK and Switzerland. Results indicated that value premiums are high and significant. Capital Asset Pricing Model (CAPM) cannot measure the returns of stocks. Fama (1991) discussed that book to market is more powerful variable in cross section return of stock. Chen, Chan and Hsieh (1985) studied company size effect and examined the size premium in large portion of companies, listed on NYSE. The result suggested that the big companies have low returns than small companies by additional risk in efficient market. Durand, Juricev and Smith (2007) used three factor model proposed by Fama and French to examine the size portfolio. Similarly, the important components are size premium (SMB) and risk premium (Rm-Rf) of the cross section of returns on Australian market, based on data from 1990 to 2001 . The results signified that the big company can earn lower returns as compared to small companies and the size premiums are statistically positive and significant. Horowitz, Loughran and Savin (2000) examined the return and size effect relationship between them and used the linear regression and regression of cross sectional method in stocks of NASDAQ, AMEX and NYSE from the period between 1980 and 1996. Result indicated that the size and return have no reliable relationship amongst them.

Review of above literature indicated that the value (book to market ratio) effect and size (small minus big) effect are recognized well in the worldwide and Pakistani evidence also exists, which is in line with the theory with same deviation regarding big stock behavior. And such observation is also reported in US market by Xing and Vassalou (2004). However, in developed markets the default risk is studied and evidence is mixed. Sometime, low default risk stocks earn more than high default risk stocks and other time high default stocks earn more than low default risk stocks. However, behavior of Pakistani market is still unexplored. This study is an effort to bridge this gap.

\section{RESEARCH METHODLOGY}

\section{Data Description}

In this study hundred Karachi stock Exchange (KSE) listed non-financial companies are used from time period 
of 2000 to 2015 and their monthly closing prices are taken. The companies are chosen on the basis of market capitalization. The reason for using 100 companies is that only few companies are frequently traded in market. So, large sample leads to selection of inactive companies.

Sample consists of non-financial sector companies. The purpose to select only the non-financial sector is that the accounting period of financial sector closes at December but the accounting period closes at July for non-financial sector. Moreover, the capital structures of financial and non-financial sectors are different.

For Pakistan, monthly stock prices have been obtained from Karachi Stock Exchange. Index data have been taken from Karachi Stock Exchange, whereas, monthly risk free rate data are taken from the State Bank of Pakistan. These are considered as reliable sources of information.

The Financial default risk premium has been calculated by using theMerton's (1974) proposed model of option-pricing methodology. For individual companies the Option pricing model is used to calculate default measures. Market cap \& BMR is calculated by using the data from annual financial reports of companies.

\section{Measurement of Variables}

The variables of size, BMR and Financial Distress Premium are calculated as under.

\section{Size}

In literature, size is measured by using Total Asset or Market Capitalization or sales.

In this study size is measured by using following formula.

$$
\text { Size }=\text { No. of share } * \text { MPS }
$$

\section{Book to Market Ratio}

Book to Market ratio is needed for sorting on the basis of value premium. The book to market ratio is calculated as under:

$$
\text { BMR }=\frac{\text { Total Equity }}{\text { Market Cap }}
$$

\section{Financial Default risk premium}

The financial default risk is calculated by using option pricing methodology proposed by Merton's (1974).

The market value of equity $\mathrm{VE}$, is calculated by the Black \& Scholes formula for Call Options.
$V_{E}=V_{A} N\left(d_{1}\right)-X e^{-{ }^{\mathrm{rT}}} N\left(d_{2}\right)$

- VE is market value of equity

- VA is the firm's assets value (total assets)

- $\mathrm{X}$ is the book value of firms liabilities (long term liabilities + current liabilities)

- $\mathrm{r}$ is risk free

- $\mathrm{T}$ is time period

Where,

$$
\begin{gathered}
d_{1}=\frac{\ln \left(V_{A} / X\right)+\left(r+1 / 2 \sigma_{A}^{2}\right) T}{\sigma \mathrm{A} \sqrt{ } \mathrm{T}} \\
\mathrm{d} 2=\mathrm{d} 1-\sigma \mathrm{A} \sqrt{\mathrm{T}}
\end{gathered}
$$

$\mathrm{r}$ is the risk-free rate, and $\mathrm{N}$ is the cumulative density function of the standard normal distribution table. Standard deviation $(\sigma \mathrm{A})$ is calculated by using formula given under

$\sigma \mathrm{A}=$

$$
\frac{\sqrt{\Sigma(\mathrm{Rm}-\mathrm{Rm})^{2}}}{\mathrm{n}}
$$

\section{Probability of Default (PD)}

Therefore we can rewrite the default probability as follows:

$\mathrm{PD}=\frac{\mathrm{N}\{-\ln (\mathrm{VA} / \mathrm{X})+(\mu-1 / 2 \sigma \mathrm{A} 2) \mathrm{T}\}}{\sigma \mathrm{A} \sqrt{\mathrm{T}}}$

Whereas,

$\mathrm{N}\left(-\mathrm{d}_{1}\right)=1-\mathrm{N}\left(\mathrm{d}_{1}\right)$

$\mu$ (Mean of change in $\ln V_{\mathrm{A}}$ ) $=\ln _{\mathrm{An}^{-1}}$

$$
\overline{\ln \mathrm{V}_{\mathrm{A}} \mathrm{o}}
$$

KMV Model is also used for estimation of distance to default (DD)

$\mathrm{DD}=\frac{\ln (\mathrm{VA} / \mathrm{X})+(\mu-1 / 2 \sigma \mathrm{A} 2) \mathrm{T}}{\sigma \mathrm{A} \sqrt{\mathrm{T}}}$

Similarly, Expected Default Probability (EDP) is calculated by using following formula.

$\mathrm{EDP}=1-\mathrm{DD}$

The normal distribution which is theoretical distribution has been used, which is implied by Merton's model.

As per the Capital Asset Pricing Model (CAPM) the 
single factor that is market premium is used to affect the returns, but according to the theory of arbitrage pricing (APT) returns are affected by many factors. Correspondingly, three factor model proposed by Fama and French $(1992,1993)$ by using market premium, value premium and size premium to affect the returns is used. Fama and French also identified financial default risk as an important priced factor. This study explored that the stock returns are influenced by the role of financial default risk premium. To find how stock returns are affected by these factors, methodology proposed by Fama and Macbeth (1973) is adopted.

\section{Portfolio Construction}

\section{Size Sorted Portfolios}

For the size sorted portfolios, the marketcapitalization for hundred companies is calculated. Then on the basis of market capitalization these companies are arranged.

Largest fifty companies are grouped as B and smallest fifty are groups as S. Average returns for both big (B) and small (S) companies have been calculated.

$$
\begin{aligned}
& \mathrm{B}=\frac{\sum \mathrm{Ri}}{\mathrm{n}} \text { Where } \mathrm{Ri}=\text { return of big companies } \\
& \mathrm{S}=\frac{\sum \mathrm{Ri}}{\mathrm{n}} \text { Where } \mathrm{Ri}=\text { return of small companies }
\end{aligned}
$$

\section{Value Sorted Portfolio}

The sample of fifty big (B) companies is further sorted on the basis of high and low book to market ratio to create book to market ratio sorted portfolios. Twenty five companies with high book to market ratio are named as $\mathrm{B} / \mathrm{H}$ and twenty five big companies with low book to market ratio are named as $\mathrm{B} / \mathrm{L}$. Average returns for both $\mathrm{B} / \mathrm{H}$ and $\mathrm{B} / \mathrm{L}$ companies are calculated.

Likewise, the sample of fifty small (S) companies is again sorted on the basis of high and low book to market ratio to create value sorted portfolios. Twenty five small companies with high book to market ratio are named as $\mathrm{S} / \mathrm{H}$ and twenty five companies with low book to market ratio are named as $\mathrm{S} / \mathrm{L}$. Average returns for $\mathrm{S} / \mathrm{H}$ and $\mathrm{S} / \mathrm{L}$ companies are calculated.

\section{Financial Default risk Sorted Portfolios}

The sample of twenty five big companies with high book to market ratio is sorted with the high default risk and low default risk to create Default risk sorted portfolios. Ten big companies with high book to market ratio and high default risk are named as $\mathrm{B} / \mathrm{H} / \mathrm{HD}$ and ten big companies with high book to market ratio and low default risk are named as B/H/LD. Ten big companies with low book to market ratio and high default risk are named as $\mathrm{B} / \mathrm{L} / \mathrm{HD}$ and ten big companies with low book to market ratio and low default risk are as named as $\mathrm{B} / \mathrm{L} /$ LD. And five mid companies are skipped as they are the average of same values and this study focuses on high default and lowest default companies to measure default risk. Average returns for each portfolio is calculated.

The sample of twenty five small companies is sorted on the basis of small companies with high book to market ratio and high default risk and small companies with high book to market ratio and low default risk to create default risk sorted portfolios. Ten small companies with high book to market ratio and high default risk are named as $\mathrm{S} / \mathrm{H} / \mathrm{HD}$ and ten small companies with high book to market ratio and low default risk are named as $\mathrm{S} / \mathrm{H} / \mathrm{LD}$. Ten small companies with low book to market ratio and high default risk are named as S/L/HD and ten small companies with low book to market ratio and low default risk are named as S/L/LD. And five mid companies are skipped as they are the average of same values and this study focuses on highly default and lowest default companies to measure default risk. Average returns for each portfolio is calculated.

The above stated method is repeated for 2000-2015. It is worth mentioning that sorting is done on June 30 each year.

\section{Variable Construction}

All portfolios average returns are such as $\mathrm{P}, \mathrm{S}, \mathrm{B}$, B/H, B/L, S/H, S/L, B/H/HD, B/H/LD, B/L/HD, B/L/ $\mathrm{LD}, \mathrm{S} / \mathrm{L} / \mathrm{HD}, \mathrm{S} / \mathrm{L} / \mathrm{LD}, \mathrm{S} / \mathrm{H} / \mathrm{HD}, \mathrm{S} / \mathrm{H} / \mathrm{LD}$ are calculated and then these averages are used to construct size premium, value premium and default risk premium. Their construction is as follows:

$$
\text { Market Premium }=\text { MKT }=(\mathrm{Rm}-\mathrm{Rf})
$$

Size Premium $(\mathrm{SMB})=$ Small Size Companies - Big Size Companies

$$
=1 / 4\{(\mathrm{~S} / \mathrm{H} / \mathrm{HD}-\mathrm{B} / \mathrm{H} / \mathrm{HD})+(\mathrm{S} / \mathrm{H} / \mathrm{LD}-\mathrm{B} / \mathrm{H} / \mathrm{LD})+
$$$$
(\mathrm{S} / \mathrm{L} / \mathrm{HD}-\mathrm{B} / \mathrm{L} / \mathrm{HD})+(\mathrm{S} / \mathrm{L} / \mathrm{LD}-\mathrm{B} / \mathrm{L} / \mathrm{LD})\}
$$

Value Premium $($ HML $)=$ High Book to Market - Low Book to Market

$$
=1 / 4\{(\mathrm{~S} / \mathrm{H} / \mathrm{HD}-\mathrm{S} / \mathrm{L} / \mathrm{HD})+(\mathrm{S} / \mathrm{H} / \mathrm{LD}-\mathrm{S} / \mathrm{L} / \mathrm{LD})+
$$$$
(\mathrm{B} / \mathrm{H} / \mathrm{HD}-\mathrm{B} / \mathrm{L} / \mathrm{HD})+(\mathrm{B} / \mathrm{H} / \mathrm{LD}-\mathrm{B} / \mathrm{L} / \mathrm{LD})\}
$$

Default risk Premium $($ HDMLD $)=$ High Default risk and Low Default risk

$$
=1 / 4\{(\mathrm{~S} / \mathrm{H} / \mathrm{HD}-\mathrm{S} / \mathrm{H} / \mathrm{LD})+(\mathrm{S} / \mathrm{L} / \mathrm{HD}-\mathrm{S} / \mathrm{L} / \mathrm{LD})+
$$$$
(\mathrm{B} / \mathrm{H} / \mathrm{HD}-\mathrm{B} / \mathrm{H} / \mathrm{LD})+(\mathrm{B} / \mathrm{L} / \mathrm{HD}-\mathrm{B} / \mathrm{L} / \mathrm{LD})\}
$$

Where,

$\mathrm{Rm}=\ln \quad$ It $/$ It-1

$\mathrm{Rm}$ stands for the market returns for month " $\mathrm{t}$ " and Itand It-1 are closing values 


\section{Model Specification}

This study is using multivariate regression with two pass regression model proposed by Fama and Macbeth (1973) methodology.

The relationship among the variables is as follow:

Return $=\alpha+\beta 1$ MKT Premium $+\beta 2$ Size premium $+\beta 3$ Value premium $+\beta 4$ Default risk premium

Returnt $=\alpha+\beta 1$ MKTt $+\beta 2$ SMBt $+\beta 3$ HMLt $+\beta 4$ HDMLDt $+\mu \mathrm{t}$

Where,

$\mathrm{R}$ is return of portfolio

$\mathrm{Rf}=$ Risk Free Rate

$\mathrm{MKT}=$ Market Premium $=\mathrm{Rm}-\mathrm{Rf}$

$\mathrm{SMB}=$ Size Premium $=$ Small - Big

$\mathrm{HML}=$ Value Premium $=$ Return of High BMR Portfolios

- Return of Low BMR Portfolios

HDMLD $=$ Default risk Premium $=$ Return of High Default risk Portfolios - Return of Low Default risk Portfolios

$\alpha=$ The Management's impact (Alpha)

$\mu \mathrm{t}=$ error term

For two pass cross section regression following econometrics relationship is used.

$\mathrm{Rp}=\lambda_{0}+\lambda 1 \beta(\mathrm{MKT})+\lambda 2 \beta(\mathrm{SMB})+\lambda 3 \beta(\mathrm{HML})+$ $\lambda 4 \beta$ (HDMLD) $+\mu \mathrm{t}$

Where,

$\beta \mathrm{MKT}=\beta$ of Market premium

$\beta \mathrm{SMB}=\beta$ of Size Premium

$\beta \mathrm{HML}=\beta$ of Value Premium $\beta$ HDMLD $=\beta$ of Default risk Premium

$\mu \mathrm{t}=$ Error term

\section{RESULTS}

\section{Empirical Results and Discussion}

Table (1) reports the statistical behavior of size, value and default risk sorted portfolios. Descriptive statistics includes mean, median, standard deviation, skewness etc.

Size sorted portfolios indicate that big stocks portfolios "B" has lower returns than the small stock "S". The results are in line with the theory as risk of big stocks is $6.5 \%$, which is higher than the risk of small stock, which exhibits $5.8 \%$ variation. Both portfolios are negatively skewed but the skewness is marginally negative. These portfolios have positive kurtosis as value of kurtosis is greater than 3 . High return earned by big stock is $22.7 \%$, whereas small portfolios earned $14.6 \%$ in a month. Moreover, maximum loss in a month is incurred by big stock, which is $29 \%$, whereas, small stock reported a maximum loss of $16.8 \%$ in a month.

When value sorted portfolios are examined, it is observed that small stock with low book to market stocks (SL) generally earned lower returns as compared to small stock low having high book to market stocks (SH). The results are consistent with the theory as risk of small stock with low book to market stock (SL) is $6.7 \%$, which is higher than the risk of small stock high book to market stock $(\mathrm{SH})$ that exhibits $6.1 \%$ variation.

TABLE 1

Descriptive Statistics Size, Value and Default risk sorted Portfolios

\begin{tabular}{lccccccc}
\hline & Mean & Median & Std Dev. & Kurtosis & Skewness & Minimum & Maximum \\
\hline P & 0.010 & 0.006 & 0.058 & 3.705 & -0.448 & -0.217 & 0.158 \\
B & 0.009 & 0.011 & 0.065 & 5.014 & -0.564 & -0.290 & 0.227 \\
S & 0.011 & 0.010 & 0.058 & 3.173 & -0.251 & -0.168 & 0.146 \\
BH & 0.008 & 0.012 & 0.072 & 6.736 & -0.503 & -0.348 & 0.315 \\
BL & 0.009 & 0.010 & 0.064 & 3.369 & -0.366 & -0.232 & 0.142 \\
SH & 0.012 & 0.008 & 0.061 & 3.219 & -0.323 & -0.189 & 0.148 \\
SL & 0.009 & 0.007 & 0.067 & 3.401 & 0.253 & -0.204 & 0.167 \\
BLHD & 0.006 & 0.013 & 0.072 & 4.639 & -0.722 & -0.327 & 0.150 \\
BLLD & 0.013 & 0.007 & 0.074 & 3.344 & -0.049 & -0.188 & 0.244 \\
BHHD & 0.009 & 0.007 & 0.090 & 12.86 & 0.412 & -0.332 & 0.576 \\
BHLD & 0.008 & 0.015 & 0.072 & 5.024 & -0.683 & -0.381 & 0.175 \\
SLHD & 0.007 & 0.005 & 0.075 & 3.987 & -0.347 & -0.274 & 0.182 \\
SLLD & 0.012 & 0.006 & 0.072 & 3.486 & 0.062 & -0.223 & 0.212 \\
SHHD & 0.013 & 0.010 & 0.071 & 3.792 & 0.091 & -0.196 & 0.292 \\
SHLD & 0.011 & 0.011 & 0.073 & 5.297 & -0.251 & -0.305 & 0.287 \\
\hline
\end{tabular}


Portfolios of small stock with high book to market stock (SH) is negatively skewed and small stock with low book to market stock (SL) is positively skewed. These portfolios have positive kurtosis as value of kurtosis is greater than 3 . High return earned by small stock with low book to market (SL) is $16.7 \%$, whereas, small stock with high book to market stock (SH) earned $14.8 \%$ in a month. Moreover, maximum loss in a month is incurred by small stock with low book to market stock (SL) is $20.4 \%$, whereas small stock high book to market stock (SH) reported a maximum loss of $18.9 \%$ in a month.

The big stock with low book to market stock (BL) has higher return than the big stock with high book to market stock $(\mathrm{BH})$. The risk of big stock with high book to market stock $(\mathrm{BH})$ is $7.2 \%$ which is higher than the risk of big stock with low book to market stock (BL) that exhibit $6.4 \%$ variation. Portfolio of big stock with high book to market stock $(\mathrm{BH})$ and big stock with low book to market stock (BL) are negatively skewed. These portfolios have positive kurtosis as value of kurtosis is greater than 3 . High return earned by big stock with high book to market stock (BH) is $31.5 \%$, whereas big stock with low book to market stock (BL) earned $14.2 \%$ in a month. Moreover, maximum loss in a month is incurred by big stock with high book to market stock $(\mathrm{BH})$ is $34.8 \%$ whereas big stock with low book to market stock (BL) reported as maximum loss of $23.2 \%$ in a month.

When default sorted portfolios are examined, that big stock with low book to market stock and low default stock $(\mathrm{B} / \mathrm{L} / \mathrm{LD})$ has higher returns than the big stock with low book to market stock and high default stock (B/L/HD). The risk of $(\mathrm{B} / \mathrm{L} / \mathrm{LD})$ is $7.4 \%$ which is higher than the risk of $(\mathrm{B} / \mathrm{L} / \mathrm{HD})$ that exhibits $7.2 \%$ variation. The portfolio of big stock with low book to market stock and high default stock (B/L/HD) and big stock with low book to market stock and low default stock (B/L/LD) are negatively skewed. These portfolios have positive kurtosis as value of kurtosis is greater than 3 . High return earned by big stock with low book to market stock and low default stock (B/L/LD) is $24.4 \%$ where as big stock with low book to market stock and high default stock (B/L/HD) earned $15 \%$ in a month. Moreover, maximum loss in a month is incurred by big stock with low book to market stock and high default stock (B/L/HD) which is $32.7 \%$ whereas big stock with low book to market stock and low default stock $(\mathrm{B} / \mathrm{L} / \mathrm{LD})$ reported a maximum loss of $18.8 \%$ in a month.

The big stock with high book to market stock and high default stock $(\mathrm{B} / \mathrm{H} / \mathrm{HD})$ has higher return than the big stock with high book to market stock and low default stocks (B/H/LD). The results are consistent with the theory as risk of big stock with high book to market stock and high default stock (B/H/HD) is $9 \%$ which is higher than the risk of big stock with high book to market stock and low default stocks $(\mathrm{B} / \mathrm{H} / \mathrm{LD})$ that exhibit $7.2 \%$ variation. The portfolio of big stock with high book to market stock and high default stock (B/H/HD) are positively skewed and the portfolio of big stock with high book to market stock and low default stocks (B/H/LD) are negatively skewed. These portfolios have positive kurtosis as value of kurtosis is greater than 3. High return earned by big stock with high book to market stock and high default stock $(\mathrm{B} / \mathrm{H} / \mathrm{HD})$ is $57.6 \%$ whereas big stock with high book to market stock and low default stocks (B/H/LD) earned $17.5 \%$ in a month. Moreover, maximum loss in a month is incurred by big stock with high book to market stock and high default stocks (B/H/HD) which is $38.1 \%$ whereas big stock with high book to market stock and low default stock $(\mathrm{B} / \mathrm{H} / \mathrm{LD})$ reported a maximum loss of $33.2 \%$ in a month

The small stock with low book to market stock and low default stocks $(\mathrm{S} / \mathrm{L} / \mathrm{LD})$ has higher return than the small stock with low book to market stock and high default stock (S/L/HD). The results are consistent with the theory as risk of small stock with low book to market stock and low default stocks ( $/ / \mathrm{L} / \mathrm{LD})$ is $7.5 \%$, which is higher than the risk of small stock with low book to market stock and high default stock (S/L/HD) that exhibit 7.4\% variation. The small stock with low book to market stock and high default stocks (S/L/HD) are negatively skewed but the small stock with low book to market stock and low default stock (S/L/LD) are positively skewed. These portfolios have positive kurtosis as value of kurtosis is greater than 3 . High return earned by small stock with low book to market stock and low default stocks $(\mathrm{S} / \mathrm{L} / \mathrm{LD})$ is $21.2 \%$ where as small stock with low book to market stock and high default stock (S/L/HD) earned $18.2 \%$ in a month. Moreover, maximum loss in a month is incurred by small stock with low book to market stock and high default stocks (S/L/HD) which is $27.4 \%$ whereas small stock with low book to market stock and low default stock $(\mathrm{S} / \mathrm{L} / \mathrm{LD})$ reported a maximum loss of $22.3 \%$ in a month.

The small stock high with book to market stock and high default stock $(\mathrm{S} / \mathrm{H} / \mathrm{HD})$ has higher returns than the small stock with high book to market stock and low default stock $(\mathrm{S} / \mathrm{H} / \mathrm{LD})$. The risk of small stock with high book to market stock and low default stock $(\mathrm{S} / \mathrm{H} / \mathrm{LD})$ is $7.3 \%$ which is higher than the risk of small stock with high book to market stock and high default stock $(\mathrm{S} / \mathrm{H} /$ HD) that exhibit $7.1 \%$ variation. The small stock with high book to market stock and low default stock $(\mathrm{S} / \mathrm{H} /$ LD) are negatively skewed and the small stock with high book to market stock and high default stock (S/H/HD) are positively skewed. These portfolios have positive kurtosis as value of kurtosis is greater than 3 . High return is earned by small stock with high book to market stock and high default stock (S/H/HD) is $29.2 \%$ whereas small 
stock with high book to market stock and low default stock $(\mathrm{S} / \mathrm{H} / \mathrm{LD})$ earned $28.7 \%$ in a month. Moreover, maximum loss in a month is incurred by small stock with high book to market stock and low default stock $(\mathrm{S} / \mathrm{H} /$ LD) which is $30.5 \%$ whereas small stock with high book to market stock and high default stock (S/H/HD) reported a maximum loss of $19.6 \%$ in a month

TABLE 2

Correlation Matrix

\begin{tabular}{lcccc}
\hline & RM-RF & SMB & HML & HDMLD \\
\hline RM-RF & 1 & & & \\
SMB & 0.160 & 1 & & \\
HML & 0.089 & 0.068 & 1 & \\
HDMLD & 0.003 & 0.340 & 0.118 & 1 \\
\hline
\end{tabular}

Table (2) reports correlation among four premiums. The market premium has non-significant positive correlation with size and value premium where as significant and positive correlation with default premium. Size premium has non-significant positive correlation with Value premium and default premium. Similarly, positive correlation is observed between value and default premium, but it is non-significant. It indicates that problem of multicolinearity does not exist.

TABLE 3

Comparative Statement of Adj. $\mathbf{R}^{2}$

\begin{tabular}{lccc}
\hline $\begin{array}{c}\text { Dependent } \\
\text { Variable }\end{array}$ & CAPM & 3FM-FF & $\begin{array}{c}\text { Default } \\
\text { Based } \\
\text { Model }\end{array}$ \\
\hline $\mathrm{P}$ & 0.502 & 0.518 & 0.597 \\
$\mathrm{~B}$ & 0.192 & 0.293 & 0.201 \\
$\mathrm{~S}$ & 0.164 & 0.274 & 0.305 \\
$\mathrm{~B} / \mathrm{H}$ & 0.177 & 0.241 & 0.264 \\
$\mathrm{~B} / \mathrm{L}$ & 0.068 & 0.225 & 0.222 \\
$\mathrm{~S} / \mathrm{H}$ & 0.229 & 0.283 & 0.257 \\
$\mathrm{~S} / \mathrm{L}$ & 0.145 & 0.255 & 0.308 \\
$\mathrm{~B} / \mathrm{H} / \mathrm{HD}$ & 0.046 & 0.234 & 0.317 \\
$\mathrm{~B} / \mathrm{H} / \mathrm{LD}$ & 0.233 & 0.286 & 0.291 \\
$\mathrm{~B} / \mathrm{L} / \mathrm{HD}$ & 0.063 & 0.113 & 0.323 \\
$\mathrm{~B} / \mathrm{L} / \mathrm{LD}$ & 0.048 & 0.164 & 0.267 \\
$\mathrm{~S} / \mathrm{H} / \mathrm{HD}$ & 0.093 & 0.324 & 0.462 \\
$\mathrm{~S} / \mathrm{H} / \mathrm{LD}$ & 0.068 & 0.232 & 0.291 \\
$\mathrm{~S} / \mathrm{L} / \mathrm{HD}$ & 0.073 & 0.167 & 0.318 \\
$\mathrm{~S} / \mathrm{L} / \mathrm{LD}$ & 0.184 & 0.347 & 0.335 \\
\hline
\end{tabular}

Comparison of the explanatory power of conventional CAPM, Fama and French three factor model and augmented model reveal that the default based model has higher adjusted $\mathrm{R}^{2}$ indicating that default risk premium is able to capture the additional information regarding returns. CAPM is valid as market premium is found significant in all portfolios but the explanatory power is very low. This indicates that there exist other factors that contribute towards the return of portfolios.

The same argument is used by Fama and French model, where size premium and value premium capture significant impact on market return. The same phenomenon is studied for default risk premium that explains return for most of the portfolio.

\section{TABLE 4}

Regression Analysis (Two pass Regression) Cross Sectional Two Pass Regression

\begin{tabular}{lllrrrc}
\hline & Coefficient & Std. Error & T Stat & P-value & ${\text { Adj. } \mathbf{R}^{2}}^{\text {Sig. F }}$ \\
\hline Intercept & 0.008 & 0.001 & 8.222 & 0.000 & 0.864 & 0.000 \\
$\beta \mathrm{Mkt}$ & 0.003 & 0.001 & 1.949 & 0.079 & & \\
Prem & & & & & & \\
$\begin{array}{l}\beta \text { Size } \\
\text { Prem }\end{array}$ & 0.002 & 0.000 & 2.563 & 0.000 & & \\
$\begin{array}{l}\beta \text { value } \\
\text { Prem }\end{array}$ & 0.001 & 0.000 & 0.730 & 0.001 & & \\
$\begin{array}{l}\beta \text { Default } \\
\text { Risk }\end{array}$ & 0.002 & 0.001 & 2.170 & 0.055 & & \\
Prem & & & & & & \\
\hline
\end{tabular}

Two pass regressions are applied on conventional portfolios to explain the predictive power of factor understandings. The results are reported in Table (4). The findings of study indicate that Market beta and default risk beta can forecast portfolios returns. However, beta of size premium and beta of value premium are significantly positively associated with the returns. The Fama and French (1996) argue that the size and value appears to contain other significant market information. The explanatory power of model is $86.4 \%$, which is good. This indicates that CAPM is relatively weak for estimating return as it is only based on market factors. However the size and value are those factors used for predicting market return.

\section{DISCUSSION}

This study analyzes the role of default risk premium in explaining equity return in Pakistan equity market. A sample of 100 non-financial companies is taken from listed companies of KSE for the period of 2000 to 2015 is used to examine the impact of various factors on equity return. The current study uses Option Pricing Model proposed by Merton's (1974) to compute default risk premium and examine the influence of default risk on equity returns.

The factors include market premium, size premium, 
value premium and default risk premium. The descriptive statistics of premiums associated with other factors are calculated and these are found positive. The value premium is highest followed by market premium and the default risk premium is found highest. The correlation among the premium is also examined and no issue of multi co-linearity is observed.

The CAPM, three factors model and default based model are tested, result of CAPM are consistent with the theory but the explanatory power is low. Results of three factors are also in track with study conducted in Pakistan (Mirza \& Shahid, 2008). Hassan and Javed (2010) examined the value premium, size premium and equity returns relationship from 2000 to 2007, in Pakistan market. Results indicate that the small portfolios returns are significantly and positively related to factor of size premium. The result of size sorted portfolios returns indicate the small size has high risk and high return but opposite results for big size; however, these are insignificant for big stocks portfolios. The value factor has positive and significant relation with all portfolios except low book to market stocks, which means that book to market effect, exists in Pakistan market. The study also states that Fama and French three factor model has higher explanatory power than CAPM. Additionally, Fama and French three factor model explains the cross section of stock returns in Karachi stock exchange (KSE).

Default risk premium is found to have negative and significant impact on small stocks and high book to market and it has significant effect on low book to market stocks. Similarly, inconsistent behavior is found in big stocks, whereas low book to market stocks have negative impact and high book to market stocks have positive impact. Hence explanatory power of the model is better than CAPM. When the default premium is added the explanatory power of the model is increased practically and default premium appears to be priced by market. This default effect is positive for high default stocks and negative for low default stocks.

\section{REFERENCES}

Agarwal, V., \& Taffler, R. (2003). The distress factor effect in equity returns: Market mispricing or omitted variable? In Staff Research Seminar Series, Manchester School of Accounting and Finance, Manchester, February

Ajili, S. (2002). The Capital Asset Pricing Model and the three Factor Model of Fama and French revisited in the case of France. Cahier de Recherché du CEREG, University Paris IX Dauphine, (2002-10), $1-26$.
Allen, D. E., \& Powell, R. (2007). Industry market value at risk in Australia (No. 2007-04).

Almeida, H., \& Philippon, T. (2007). The risk-adjusted cost of financial distress. The Journal of Finance, 62(6), 2557-2586.

Altman, E. I. (1968). Financial ratios, discriminant analysis and the prediction of corporate bankruptcy. The Journal of Finance, 23(4), 589-609.

Amihud, Y. (2002). Illiquidity and stock returns: crosssection and time-series effects. Journal of Financial Markets, 5(1), 31-56.

Amihud, Y., \& Mendelson, H. (1986). Liquidity and stock returns. Financial Analysts Journal, 42(3), 43-48.

Anginer, D., \&Yildizhan, C. (2014). Is there a distress risk anomaly? Pricing of systematic default risk in the cross section of equity returns. Pricing of Systematic Default Risk in the Cross Section of Equity Returns (May 19, 2014).

Auret, C. J., \& Sinclaire, R. A. (2006). Book-to-market ratio and returns on the JSE. Investment Analysts Journal, 35(63), 31-38.

Avramov, D., Chordia, T., Jostova, G., \& Philipov, A. (2007). Momentum and credit rating. The Journal of Finance, 62(5), 2503-2520.

Bahl, B. (2006). Testing the Fama and French Threefactor model and its variants for the Indian stock returns. Available at SSRN 950899.

Banz, R. W. (1981). The relationship between return and market value of common stocks. Journal of Financial Economics, 9(1), 3-18.

Barber, B. M., \& Lyon, J. D. (1997). Firm size, book-tomarket ratio, and security returns: a holdout sample of financial firms. The Journal of Finance, 52(2), 875-883.

Basu, S. (1983). The relationship between earnings' yield, market value and return for NYSE common stocks: Further evidence. Journal of Financial Economics, 12(1), 129-156.

Berndt, A., Lookman, A. A., \& Obreja, I. (2007, September). Default risk Premia and asset returns. In AFA 2007 Chicago Meetings Paper.

Bharath, S. T., \& Shumway, T. (2004, December). Forecasting default with the KMV-Merton model. In AFA 2006 Boston Meetings Paper.

Bharath, S. T., \& Shumway, T. (2004, December). Forecasting default with the KMV-Merton model. In AFA 2006 Boston Meetings Paper.

Bharath, S. T., \& Shumway, T. (2008). Forecasting default with the Merton distance to default model. Review of Financial Studies, 21(3), 1339-1369.

Black, F. (1972). Capital market equilibrium with restricted borrowing. The Journal of Business, 45(3), 444-455. 
Black, F., \& Scholes, M. (1973). The pricing of options and corporate liabilities. The Journal of Political Economy, 81(3), 637-654.

Breig, C., \& Elsas, R. (2007). The Impact of Default Risk on Equity Returns: Evidence from a BankBased Financial System. Working Paper.

Brennan, M. J., \& Wang, A. (2001). Intertemporal capital asset pricing and the Fama-French threefactor model.

Bystrom, H., Worasinchai, L., \& Chongsithipol, S. (2005). Default risk, systematic risk and Thai firms before, during and after the Asian crisis. Research in International Business and Finance, 19(1), 95110.

Campbell, J. Y., Hilscher, J., \& Szilagyi, J. (2004). nIn search of distress risk, Working Paper. Harvard University.

Campbell, J. Y., Hilscher, J., \& Szilagyi, J. (2008). In search of distress risk. The Journal of Finance, 63(6), 2899-2939.

Carhart, M. M. (1997). On persistence in mutual fund performance. The Journal of finance, 52(1), 57-82

Chan, H., Faff, R., \& Kofman, P. (2011). Is default risk priced in Australian equity? Exploring the role of the business cycle. Australian Journal of Management, 36(2), 217-246.

Chan, K., Chen, N. F., \& Hsieh, D. A. (1985). An exploratory investigation of the firm size effect. Journal of Financial Economics, 14(3), 451-471.

Chava, S., \& Purnanandam, A. (2010). Is default risk negatively related to stock returns? Review of Financial Studies, 29(12), 1-62.

Chava, S., \& Purnanandam, A. (2010). Is default risk negatively related to stock returns? Review of Financial Studies, hhp107

Chen, J. (2002, May). Intertemporal CAPM and the cross-section of stock returns. In EFA 2002 Berlin Meetings Discussion Paper.

Chen, L., Petkova, R., \& Zhang, L. (2008). The expected value premium. Journal of Financial Economics, 87(2), 269-280.

Chen, N. F., Roll, R., \& Ross, S. A. (1986). Economic forces and the stock market. Journal of Business, 59(3), 383-403.

Chung, Y. P., Johnson, H., \& Schill, M. J. (2006). Asset Pricing When Returns Are Nonnormal: FamaFrench Factors versus Higher-Order Systematic Comoments*. The Journal of Business, 79(2), 923940.

Chung, Y. P., Johnson, H., \& Schill, M. J. (2006). Asset Pricing When Returns Are Nonnormal: FamaFrench Factors versus Higher-Order Systematic Comoments*. The Journal of Business, 79(2), 923940
Cochrane, J. H. (1991). A simple test of consumption insurance. Journal of Political Economy, 99(5), 957-976.

Conrad, J., \& Kaul, G. (1988). Time-variation in expected returns. Journal of Business, 61(4), 409-425.

Cooper, I. A., \& Mello, A. S. (1991). The default risk of swaps. The Journal of Finance, 46(2), 597-620.

Cox, T. (1985). The nature and measurement of stress. ergonomics, 28(8), 1155-1163.

Da, Z., \&Gao, P. (2005). Default Risk and Equity Return: Macro Effect or Micro Noise? Available at SSRN 659241

Das, S. R., Freed, L., Geng, G., \& Kapadia, N. (2002). Correlated default risk. In EFA 2003 Annual Conference Paper (No. 928).

Das, S. R., Freed, L., Geng, G., \& Kapadia, N. (2002). Correlated default risk. In EFA 2003 Annual Conference Paper (No. 928).

Dempsey, M. (2010). The book-to-market equity ratio as a proxy for risk: evidence from Australian markets. Australian Journal of Management, 35(1), 7-21.

Dichev, I. D. (1998). Is the risk of bankruptcy a systematic risk?. The Journal of Finance, 53(3), 1131-1147.

Duffee, G. R. (1999). Estimating the price of default risk. Review of Financial Studies, 12(1), 197-226.

Durand, R. B., Juricev, A., \& Smith, G. W. (2007). SMB - arousal, disproportionate reactions and the size-premium. Pacific-Basin Finance Journal, 15(4), 315-328.

Elton, E. J. (1999). Presidential address: expected return, realized return, and asset pricing tests. The Journal of Finance, 54(4), 1199-1220.

Erlenmaier, U., \& Gersbach, H. (2014). Default Correlations in the Merton Model. Review of Finance, 18(5), 1775-1809

Fama, E. F., \& French, K. R. (1995). Size and book-tomarket factors in earnings and returns. The Journal of Finance, 50(1), 131-155.

Fama, E. F., \& French, K. R. (1996). The CAPM is wanted, dead or alive. The Journal of Finance, 51(5), 1947-1958.

Fama, E. F., \& French, K. R. (1997). Industry costs of equity. Journal of Financial Economics, 43(2), 153-193.

Fama, E. F., \& French, K. R. (2004). The capital asset pricing model: Theory and evidence. The Journal of Economic Perspectives, 18(3), 25-46.

Fama, E. F., \& French, K. R. (2006). The value premium and the CAPM. The Journal of Finance, 61(5), 2163-2185

Fama, E. F., \& French, K. R. (2012). Size, value, and momentum in international stock returns. Journal of Financial Economics, 105(3), 457-472.

Fama, E. F., \& French, K. R. (2015). A five factor 
asset pricing models. The Journal of Financial Economics, 116(2015), 1-22.

Fan, H., \& Sundaresan, S. M. (2000). Debt valuation, renegotiation, and optimal dividend policy. Review of Financial Studies, 13(4), 1057-1099.

Gao, P., Parsons, C. A., \&Shen, J. (2013). The global relation between financial distress and equity returns. Available at SSRN 2086475.

Garlappi, L., \& Yan, H. (2011). Financial Distress and the Cross-section of Equity Returns. The Journal of Finance, 66(3), 789-822.

Garlappi, L., \& Yan, H. (2011). Financial distress and the cross-section of equity returns. The Journal of Finance, 66(3), 789-822.

Garlappi, L., Shu, T., \& Yan, H. (2008). Default risk, shareholder advantage, and stock returns. Review of Financial Studies, 21(6), 2743-2778.

Garlappi, L., Shu, T., \& Yan, H. (2008). Default risk, shareholder advantage, and stock returns. Review of Financial Studies, 21(6), 2743-2778.

Gertner, R. H., Scharfstein, D. S., \& Stein, J. C. (1994). Internal versus external capital markets (No. w4776). National Bureau of Economic Research.

Gharghori, P., Chan, H., \& Faff, R. (2007). Are the FamaFrench factors proxying default risk? Australian Journal of Management, 32(2), 223-249.

Gharghori, P., Chan, H., \& Faff, R. (2009). Default risk and equity returns: Australian evidence. PacificBasin Finance Journal, 17(5), 580-593.

Griffin, J. M. (2002). Are the Fama and French factors global or country specific? Review of Financial Studies, 15(3), 783-803.

Hacking, I. (1990). The taming of chance (Vol. 17). Cambridge University Press.

Harvey, C. R. (1989). Time-varying conditional covariance in tests of asset pricing models. Journal of Financial Economics, 24(2), 289-317.

Hassan, A., \& Javed, M. T. (2011). Size and value premium in Pakistani equity market. African Journal of Business Management, 5(16), 6747.

Hiang Liow, K., \& Chuan Sim, M. (2006). The risk and return profile of Asian real estate stocks. Pacific Rim Property Research Journal, 12(3), 283-310.

Hillegeist, S. A., Keating, E. K., Cram, D. P., \& Lundstedt, K. G. (2004). Assessing the probability of bankruptcy. Review of Accounting Studies, 9(1), 5-34.

Ho, T. S., \& Singer, R. F. (1982). Bond indenture provisions and the risk of corporate debt. Journal of Financial Economics, 10(4), 375-406.

Holst, A. D. C., \& Martynenko, O. (2010). Default Risk in Equity Returns.

Horowitz, J. L., Loughran, T., \& Savin, N. E. (2000). Three analyses of the firm size premium. Journal of Empirical Finance, 7(2), 143-153.

Hsu, J. C., Saa-Requejo, J., \& Santa-Clara, P. (2004). Bond pricing with default risk. Available at SSRN 611401.

Hull, J., \& White, A. (1992). The price of default. Risk, 5(8), 101-103.

Hull, J., Predescu, M., \& White, A. (2004). The relationship between credit default swap spreads, bond yields, and credit rating announcements. Journal of Banking \& Finance, 28(11), 2789-2811.

Jegadeesh, N., \& Titman, S. (1993). Returns to buying winners and selling losers: Implications for stock market efficiency. The Journal of Finance, 48(1), 65-91.

Johnson, H., \& Stulz, R. (1987). The pricing of options with default risk. The Journal of Finance, 42(2), 267-280.

Kealhofer, S., \& Bohn, J.R.(1998). Portfoliomanagement of default risk. Net Exposure, 1(2), 12-40.

Korteweg, A. (2010). The net benefits to leverage. The Journal of Finance, 65(6), 2137-2170.

Lintner, J. (1965). Security prices, risk, and maximal gains from diversification. The Journal of Finance, 20(4), 587-615.

Lintner, J. (1965). The valuation of risk assets and the selection of risky investments in stock portfolios and capital budgets. The Review of Economics and Statistics, 47(1), 13-37.

Longstaff, F.A., \& Schwartz, E. S. (1993). Implementation of the Longstaff-Schwartz interest rate model. The Journal of Fixed Income, 3(2), 7-14.

MacKinlay, A. C. (1995). Multifactor models do not explain deviations from the CAPM. Journal of Financial Economics, 38(1), 3-28.

Madan, D. B., \&Unal, H. (1998). Pricing the risks of default. Review of Derivatives Research, 2(2-3), 121-160.

Malik, U. S., Aftab, M., \& Noreen, U. (2013). Distress Risk and Stock Returns in an Emerging Market. Research Journal of Finance and Accounting, 4(17), 81-85.

Markowitz, H. (1952). Portfolio selection. The Journal of Finance, 7(1), 77-91.

Markowitz, H. M. (1991). Foundations of portfolio theory. The Journal of Finance, 46(2), 469-477.

Merton, R. C. (1973). Theory of rational option pricing. The Bell Journal of Economics and Management Science, 4(1), 141-183.

Merton, R. C. (1974). On the pricing of corporate debt: The risk structure of interest rates. The Journal of Finance, 29(2), 449-470.

Mirza, N., \& Shahid, S. (2008). Size and value premium in Karachi stock exchange.

Ohlson, J.A. (1980). Financial ratios and the probabilistic 
prediction of bankruptcy. Journal of Accounting Research, 18(1), 109-131.

Opler, T. C., \& Titman, S. (1994). Financial distress and corporate performance. The Journal of Finance, 49(3), 1015-1040.

O'Sullivan, F., Hwang, J. G., Zahn, M., Hjortstam, O., Pettersson, L., Liu, R., \& Biller, P. (2008, June). A model for the initiation and propagation of positive streamers in transformer oil. In Electrical Insulation, 2008. ISEI 2008. Conference Record of the 2008 IEEE International Symposium on (pp. 210-214). IEEE.

Patel, K., \& Vlamis, P. (2006). An empirical estimation of default risk of the UK real estate companies. The Journal of Real Estate Finance and Economics, 32(1), 21-40

Patel, K., \& Vlamis, P. (2006). An empirical estimation of default risk of the UK real estate companies. The Journal of Real Estate Finance and Economics, 32(1), 21-40.

Reinganum, M. R. (1981). The arbitrage pricing theory: Some empirical results. The Journal of Finance, 36(2), 313-321.

Rosenberg, B., Reid, K., \& Lanstein, R. (1985). Persuasive evidence of market inefficiency. The Journal of Portfolio Management, 11(3), 9-16.

Ross, S. A. (1976). The arbitrage theory of capital asset pricing. Journal of Economic Theory, 13(3), 341360.

Rubinstein, M. (1976). The valuation of uncertain income streams and the pricing of options. The Bell Journal of Economics, 7(2), 407-425.
Sharma, R., \& Mehta, K. (2013). Fama and French: Three factor model. SCMS Journal of Indian Management, 10(2),90.

Sharpe, W. F. (1964). Capital asset prices: A theory of market equilibrium under conditions of risk. The Journal of Finance, 19(3), 425-442.

Shumway, T. (2001). Forecasting bankruptcy more accurately: A simple hazard model*. The Journal of Business, 74(1), 101-124.

Spyrou, S., \& Kassimatis, K. (2009). Time-variation in the value premium and the CAPM: evidence from European markets. Applied Financial Economics, 19(23), 1899-1914.

Stattman, D. (1980). Book values and stock returns. The Chicago MBA: A Journal of Selected Papers, 4(1), 25-45.

Tobin, J. (1958). Liquidity preference as behavior towards risk. The Review of Economic Studies, 25(2), 65-86.

Van Dijk, M. A. (2011). Is size dead? A review of the size effect in equity returns. Journal of Banking \& Finance, 35(12), 3263-3274.

Vassalou, M., \& Xing, Y. (2004). Default risk in equity returns. The Journal of Finance, 59(2), 831-868.

Xing, Y. (2004). Firm investments and expected equity returns. Working paper, Rice University.

Zhou, C. (2001). An analysis of default correlations and multiple defaults. Review of Financial Studies, 14(2), 555-576

Zmijewski, M. E. (1984). Methodological issues related to the estimation of financial distress prediction models. Journal of Accounting Research, 59-82. 